\title{
Evaluating Insects as Bioindicators of Heavy Metal Contamination and Accumulation near Industrial Area of Gujrat, Pakistan
}

\author{
Iqra Azam, ${ }^{1}$ Sumera Afsheen, ${ }^{1}$ Ahmed Zia, ${ }^{2}$ Muqaddas Javed, ${ }^{3}$ Rashid Saeed, ${ }^{4}$ \\ Muhammad Kaleem Sarwar, ${ }^{1}$ and Bushra Munir ${ }^{5}$ \\ ${ }^{1}$ Department of Zoology, Institute of Life Sciences, University of Gujrat, Punjab 50700, Pakistan \\ ${ }^{2}$ National Insect Museum, National Agriculture Research Centre, Islamabad, Pakistan \\ ${ }^{3}$ Department of Statistics, University of Gujrat, Punjab 50700, Pakistan \\ ${ }^{4}$ Department of Environmental Sciences, Institute of Life Sciences, University of Gujrat, Punjab 50700, Pakistan \\ ${ }^{5}$ Department of Applied Chemistry and Biochemistry, Government College University of Faisalabad, Punjab 38000, Pakistan
}

Correspondence should be addressed to Sumera Afsheen; sumera.afsheen@uog.edu.pk

Received 12 February 2015; Revised 16 April 2015; Accepted 16 April 2015

Academic Editor: Chong-Jian Tang

Copyright (C) 2015 Iqra Azam et al. This is an open access article distributed under the Creative Commons Attribution License, which permits unrestricted use, distribution, and reproduction in any medium, provided the original work is properly cited.

\begin{abstract}
To study the accumulation and contamination of heavy metals (i.e., $\mathrm{Cd}, \mathrm{Cr}, \mathrm{Cu}, \mathrm{Ni}$, and $\mathrm{Zn}$ ) in soil, air, and water, few insect species were assayed as ecological indicators. Study area comes under industrial zone of district Gujrat of Punjab, Pakistan. Insects used as bioindicators included a libellulid dragonfly (Crocothemis servilia), an acridid grasshopper (Oxya hyla hyla), and a nymphalid butterfly (Danaus chrysippus) near industrial zone of Gujrat. Accumulation of $\mathrm{Cd}$ was highest in insect species followed by $\mathrm{Cu}$, $\mathrm{Cr}, \mathrm{Zn}$, and $\mathrm{Ni}$ at $p<0.05$. Hierarchical cluster analysis (HACA) was carried out to study metal accumulation level in all insects. Correlation and regression analysis confirmed HACA observations and declared concentration of heavy metals above permissible limits. Metal concentrations in insects were significantly higher near industries and nallahs in Gujrat and relatively higher concentrations of metals were found in Orthoptera than Odonata and Lepidoptera. The total metal concentrations in insects were pointed significantly higher at sites S3 (Mid of HalsiNala), S9 (End of HalsiNala), and S1 (Start of HalsiNala), whereas lowest value was detected at site S6 (Kalra Khasa) located far from industrial area. HACA indicates that these insect groups are potential indicators of metal contamination and can be used in biomonitoring.
\end{abstract}

\section{Introduction}

Natural ecosystems all over the world have been adversely affected by human interventions [1]. Modern farming, industrialization, and increased vehicular use have led to high concentrations of heavy metals such as lead, nickel, chromium, cadmium, aluminum, mercury, and zinc in the environment [2]. These toxic heavy metals are regularly getting into air, water, and soil, thereby becoming part of natural biogeochemical cycle [3]. Insects have strong relationship with ecology and are popularly used as bioindicators since long time [4]. Acute and chronic effects of heavy metals on various insects are frequently reported in the form of growth inhibition, developmental abnormalities, reduced reproduction, and decreased hatchability [5].

Among aquatic insects, dragonflies are taken as being most sensitive to habitat disturbance [6]. Their presence in any water body confirms its synthetic pollution-free status [7]. Ecologically they are good indicator of the condition of terrestrial as well as aquatic ecosystems $[8,9]$. Butterflies and grasshoppers also have ecological fidelity and are sensitive to environmental changes and quality. According to Chen et al. [10] these insects have been successfully used as bioindicators for environmental pollution and heavy metals contaminations near industrial states and even within urban areas. 

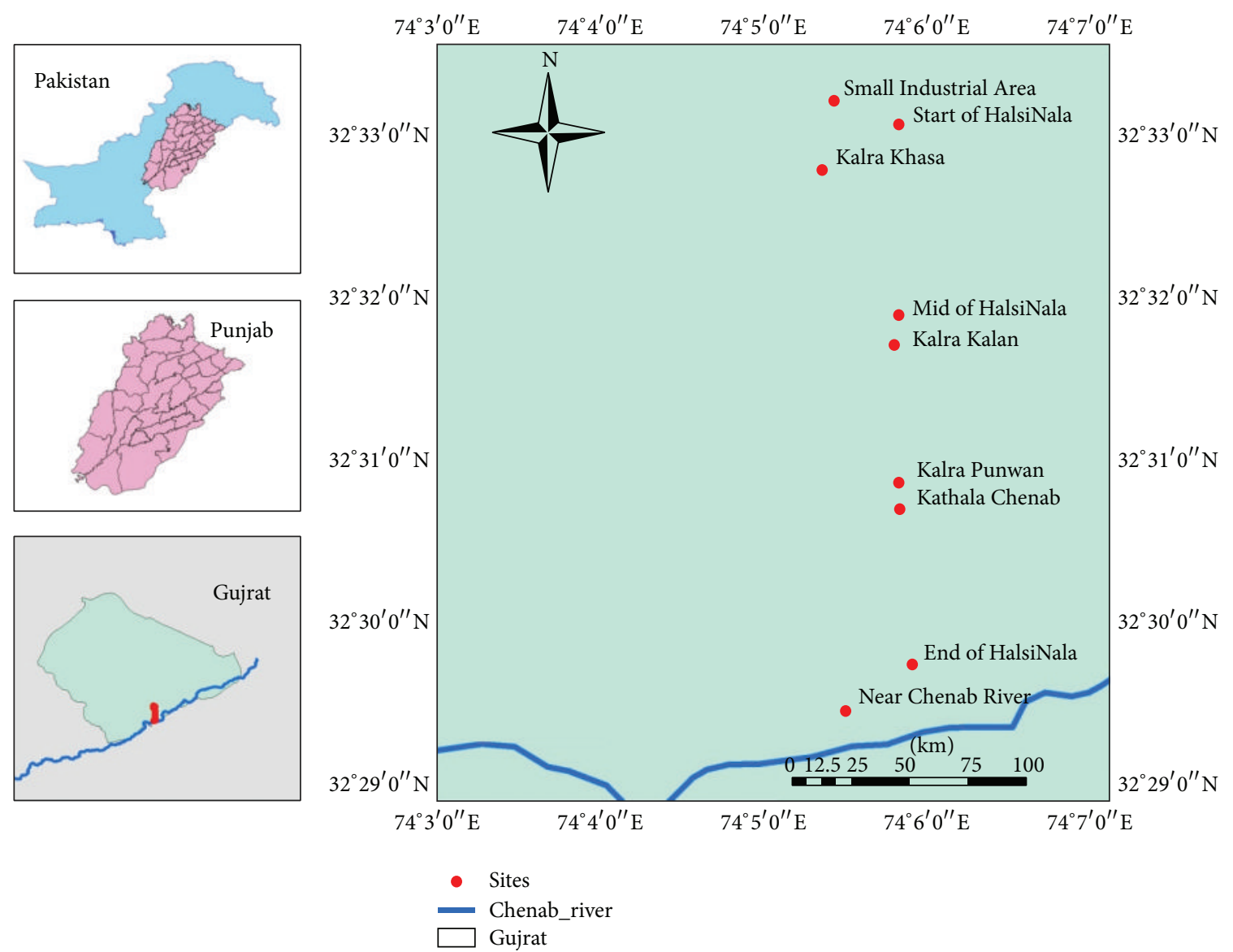

FIGURE 1: Map showing sampling sites (Arc GIS 9.3).

The reasons for using these insect species as indicator are follows: (1) use of several different taxa of different habitat gives more robust results, (2) a quantitative indicator value needs to be associated with the bioindicators, (3) there is similarity between different landscape features, (4) there is comparison of community, (5) these taxa can be reliably identified, sampled, and quantified, and (6) more than one family surely indicate species richness of an order [11]. At landscape level, strong correlation is found among grasshoppers (herbivore) and butterflies (nectivore and herbivore). Furthermore for bioindication of ecological change we used aquatic insect dragonfly (Order Odonata). They are considered as best ecological indicator in water and riparian systems. They give a rapid and sensitive response to accumulation of heavy metals [12].

Gujrat is an important industrial area of Punjab province of Pakistan. It is business bay for ceramics, fan, furniture, and leather industry. Qadir et al. [13] reported more than 1000 cottage-level to large-scale industrial units from this district. In recent past structure, ground water, and landscape of Gujrat have been reported to be rapidly degraded due to industrialization, increased urbanization, and modern agricultural activities leading to injudicious use of pesticides and fertilizers [14]. Keeping in view environmental and health concerns due to increased heavy metal contamination, present study was designed to investigate level of heavy metal contamination in district Gujrat by using insects as bioindicators.

\section{Materials and Methods}

Survey to study heavy metal contamination was carried out during September 2013 to August 2014 in nine localities (Start of HalsiNala (S1), Kalra Punwan (S2), Mid of HalsiNala (S3), Small Industrial Area (S4), Kalra Kalan (S5), Kalra Khasa (S6), Kathala Chenab (S7), Near Chenab River (S8), and End of Nala (S9)) of Tehsil Gujrat (Figure 1). Details regarding coordinates and vegetation cover at each sampling site are shown in Table 1 . Sites were selected at nearest possible distance to the functioning industrial units. Three insects groups were chosen to be used as bioindicators. It included a libellulid dragonfly (Crocothemis servilia), a nymphalid butterfly (Danaus chrysippus), and an acridid grasshopper (Oxya hyla hyla). These were collected from rice and wheat crops on quarterly basis for a period of one year. Three specimens of each group were recorded from each site so the total number of specimens (sample size) becomes twenty-seven for each species (Table 2). Soil and plant samples were also collected from same sites and stored in sterilized polythene bags until reaching laboratory. Represented specimens of each group 


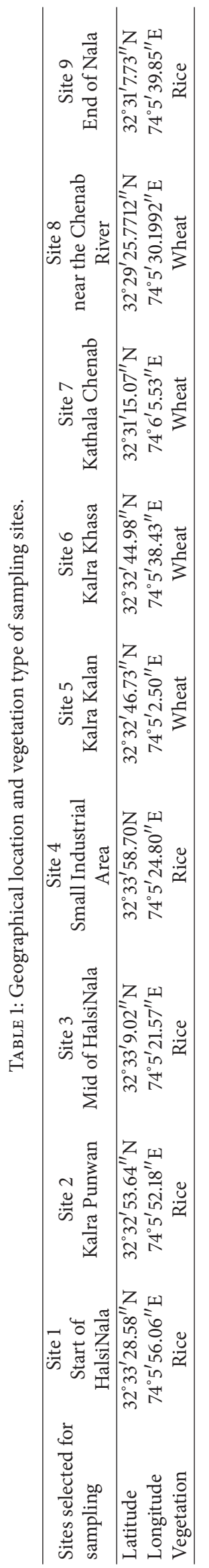




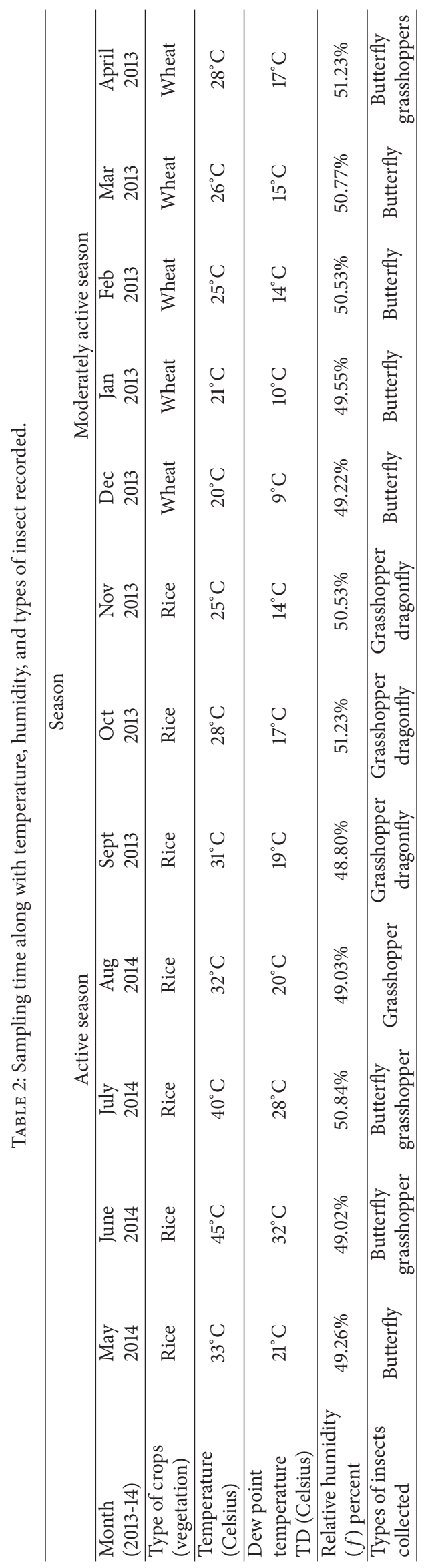


were sent to National Insect Museum, NARC, Islamabad for taxonomic confirmation.

Gujrat is the most important industrial district of Punjab. Here the main sources of pollution in this region include smoke from chimneys, sewage water released into "HalsiNala", and toxic waste dump sites. Contaminated water from "HalsiNala" is used for irrigation purposes in nearby fields that ultimately affect crops leading to heavy metal accumulation. Insects were collected from nine sites of industrial area $\left(32^{\circ} 33^{\prime} 28.58^{\prime \prime} \mathrm{N}, 74^{\circ} 5^{\prime} 56.06^{\prime \prime} \mathrm{E}\right.$ to $\left.32^{\circ} 31^{\prime} 7.73^{\prime \prime} \mathrm{N}, 74^{\circ} 5^{\prime} 39.85^{\prime \prime} \mathrm{E}\right)$ for the assessment of heavy metals $(\mathrm{Cu}, \mathrm{Zn}, \mathrm{Cd}, \mathrm{Ni}$, and $\mathrm{Cr}$ ).

Insects were mechanically dried in oven, weighed on microbalance, and digested in a mixture of supra pure grade nitric acid and perchloric acid mixed 4:1. Digests were analyzed for metal contents using atomic absorption spectrophotometer in an air-acetylene flame for zinc and copper and in a PU-93 090X graphite furnace for copper, chromium, cadmium, nickel and zinc.

Descriptive statistics, analysis of variance (one-way) ANOVA, bivariate correlation, and regression analysis were made on recorded data by testing significance differences at $p<0.05$ using SPSS 16.0. Site dependent statistical differences between mean concentrations of heavy metals in each of the insect taxa were examined using descriptive statistics. Hierarchical cluster analysis (HACA) based on agglomerative statistics using Ward's Method was calculated for concentration of heavy metals at each of the sampling sites.

\section{Results and Discussion}

All studied sites generally showed remarkable species based variations in metal concentrations (Figure 2). Highest metal concentration was observed in the Danaus chrysippus from "End of Nala." Significant site-based differences in levels of contamination were observed in the mean concentration of heavy metals at each site; however it varied up to threefold between examined species (Table 3). Lowest heavy metal concentration was seen in Danaus chrysippus specimens recorded from Kalra Punwan (S2). Apparent species dependent differences in metal pollution gradient were found in each examined species. All sampled soils were found to be slightly acidic, showing $\mathrm{pH}$ around neutrality (Table 4). Larger differences were however observed for organic matter contents and available phosphorus (Table 9). Descriptive statistics for soluble salts and other properties of water samples taken from nine sites is shown in Table 5.

Nonparametric test was also carried out for obtained data of this study. Two-independent-sample tests by MannWhitney test for two values and $K$ independent tests by Kruskal-Wallis test and Jonckheere-Terpstra test were done to compare means of data. The distribution as shown in Table 7 indicates that season, site, crop, and HMG show insignificant results while metals show significant results at $p<0.05$. It was thus likewise accepted that season, site, crop, and HMG have equal effect on accumulation of heavy metals in insect's body. On the other hand type of metal does not show equal effect and gave significant results at $p<0.05$.
Variation within each parameter of soil and water showed their effect on each other (Table 7). EC, OM, AK, and $S$ showed significant results in soil at $p<0.05$, while AP displayed insignificant results and hence $\mathrm{pH}$ and AP showed equal effect. In water parameters all factors displayed significant results at $5 \%$ level of significance.

Correlations between metals were also studied and found predominantly positive in the case of $\mathrm{Cd}$ and $\mathrm{Cr}$ (Table 8). However it was observed to be positive as well as negative in case of $\mathrm{Ni}, \mathrm{Zn}$, and $\mathrm{Cu}$. $\mathrm{Zn}$ concentrations were speciesspecific and correlation with $\mathrm{Zn}$, Ni level in humus layer was statistically insignificant. Significant correlation was found between $\mathrm{Cd}, \mathrm{Zn}$, and $\mathrm{Cr}$ in O. hyla hyla $\mathrm{Cd}, \mathrm{Zn}$, and $\mathrm{Cr}$ in C. servilia $(p<0.05)$. But strongly positive relationship was observed between $\mathrm{Zn}$ and $\mathrm{Cr}$ in D. chrysippus and $\mathrm{Zn}, \mathrm{Cr}$, and $\mathrm{Cd}$ in O. hyla hyla. Similarly in C. servilia strong positive relationship was seen between $\mathrm{Cr}$ and $\mathrm{Cu}, \mathrm{Cr}$ and $\mathrm{Zn}, \mathrm{Cd}$, and $\mathrm{Ni}$. Body level of $\mathrm{Cr}$, Cd correlated negatively with those of $\mathrm{Ni}$ and $\mathrm{Cu}$ in O. hyla hyla and D. chrysippus species except for $C$. servilia.

Table 11 explains the regression analysis of heavy metals group (O. hyla hyla, C. servilia, and D. chrysippus) using copper $(\mathrm{Cu})$, chromium $(\mathrm{Cr})$, and cadmium $(\mathrm{Cd})$, as dependent for each insect group. By critically evaluating Table 11 it is concluded that the model of $O$. hyla hyla which contain copper $(\mathrm{Cu})$ and chromium $(\mathrm{Cr})$ as dependent is insignificant and the independent variables moderately explain the variation of dependent variables. Whereas the model of $O$. hyla hyla which contain cadmium as dependent variable and nickel $(\mathrm{Ni})$, zinc $(\mathrm{Zn})$, chromium $(\mathrm{Cr})$, and copper $(\mathrm{Cu})$ as independent is significant, independent variables can explain $88 \%$ variation of dependent variable and all $\beta$ are significant. So overall we can conclude that the model which contains cadmium as dependent variable is suitable to explain metal toxicity in O. hyla hyla.

The models of $C$. servilia which contain copper $(\mathrm{Cu})$ and chromium $(\mathrm{Cr})$ as dependent are insignificant and the independent variables moderately explain the variation of dependent variables, whereas the model of $C$. servilia which contain cadmium $(\mathrm{Cd})$ as dependent variable and nickel $(\mathrm{Ni})$, zinc $(\mathrm{Zn})$, chromium $(\mathrm{Cr})$, and copper $(\mathrm{Cu})$ as independent is significant. Independent variables can explain $88 \%$ variation of dependent variable and all $\beta$ are significant. So overall we can conclude that the model which contains cadmium as dependent variable is suitable to explain the C. servilia metal toxicity.

In regression model for third group (D. chrysippus) which contain copper $(\mathrm{Cu})$ and chromium $(\mathrm{Cr})$ and cadmium $(\mathrm{Cd})$ as dependent, all are insignificant. By critically observing values of all $\beta$, we conclude that overall model is weak. Hence copper $(\mathrm{Cu})$ and chromium $(\mathrm{Cr})$ and cadmium $(\mathrm{Cd})$ cannot be used to represent the metal concentrations of all other metals. Our results of predictive model clearly demonstrated that these metals have different anthropogenic source and their concentrations are not explained relative to each other.

Hierarchical agglomerative cluster analysis (HACA) was also evaluated to assess concentration of heavy metals in urban soils and to check environmental quality; for each data set (three insect taxa) multivariate cluster analysis using SPSS 

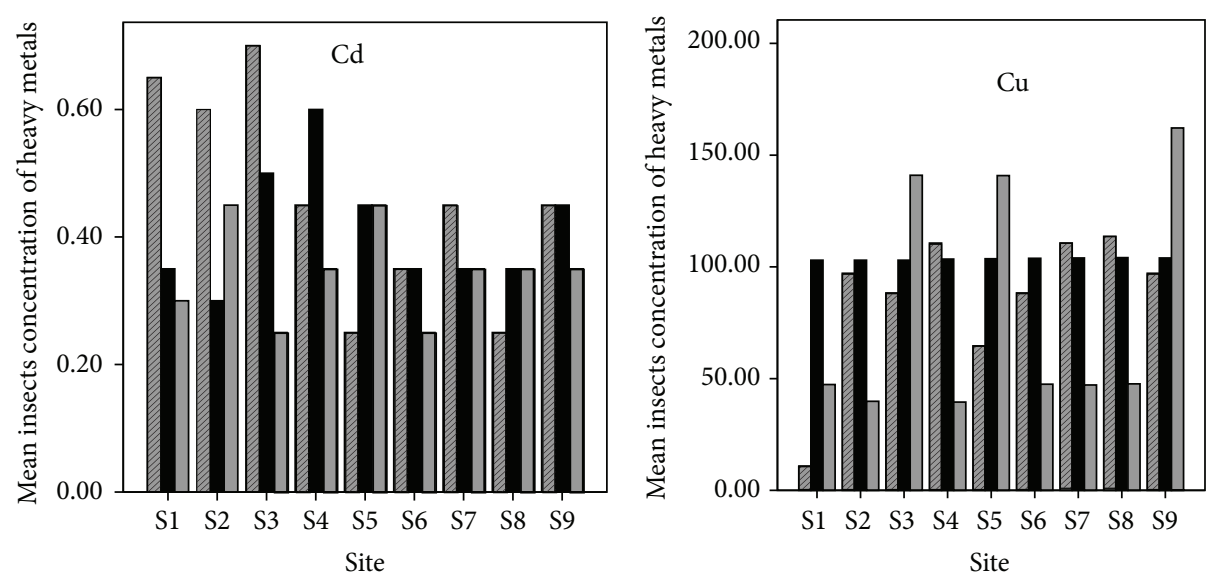

(a)

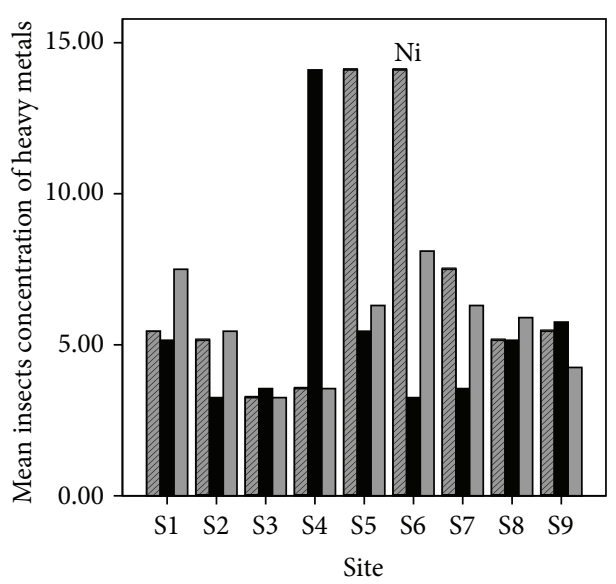

(b)

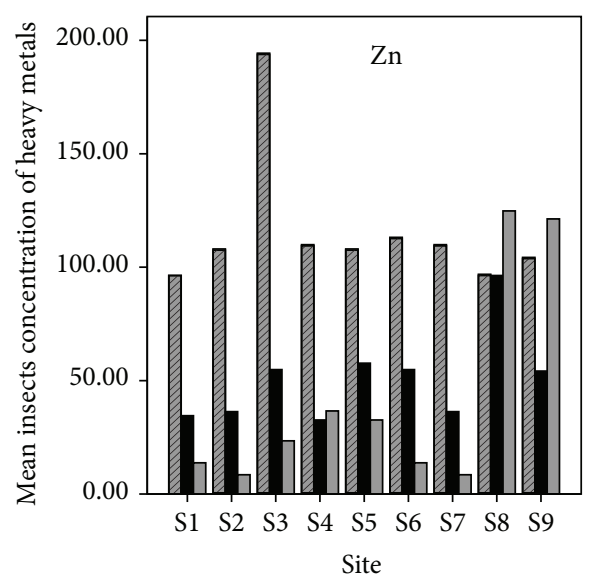

(c)

(d)

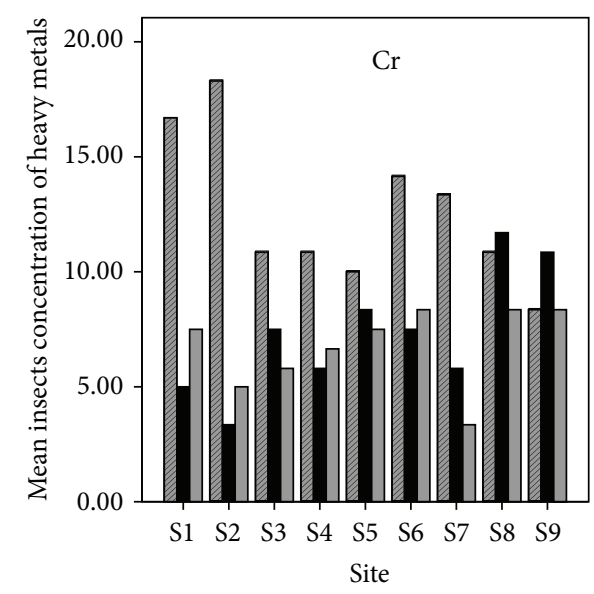

HMG

$\square$ Grasshopper

- Dragonfly

$\square$ Butterfly

(e)

FIGURE 2: Mean values and standard deviations of metal concentrations in three insect taxa. 
TABLE 3: Mean concentrations of metals $(\mathrm{mg} / \mathrm{L}) \pm$ S.D. recorded in three insect taxa.

\begin{tabular}{lcccc}
\hline Site & Number & O. hyla hyla & C. servilia & D. chrysippus \\
\hline Start of HalsiNala & 5 & $25.96 \pm 39.79$ & $29.61 \pm 43.21$ & $15.20 \pm 18.50$ \\
Kalra Punwan & 5 & $45.74 \pm 52.00$ & $29.20 \pm 43.80$ & $11.80 \pm 15.90$ \\
Mid of HalsiNala & 5 & $59.39 \pm 83.00$ & $33.88 \pm 44.57$ & $34.70 \pm 60.07$ \\
Small Industrial Area & 5 & $46.98 \pm 57.60$ & $31.33 \pm 42.14$ & $17.33 \pm 19.07$ \\
Kalra Kalan & 5 & $39.30 \pm 45.50$ & $35.12 \pm 44.74$ & $37.55 \pm 59.05$ \\
Kalra Khasa & 5 & $45.92 \pm 50.87$ & $33.95 \pm 44.97$ & $15.50 \pm 18.45$ \\
Kathala Chenab & 5 & $48.27 \pm 56.56$ & $30.01 \pm 43.81$ & $13.13 \pm 19.26$ \\
Near the Chenab River & 5 & $45.25 \pm 55.01$ & $43.54 \pm 51.99$ & $37.41 \pm 52.32$ \\
End of Nala & 5 & $43.04 \pm 52.55$ & $35.05 \pm 44.05$ & $59.20 \pm 76.60$ \\
\hline
\end{tabular}

TABLE 4: Descriptive statistics for $\mathrm{pH}, \mathrm{EC}, \mathrm{OM}$, and other properties in urban soil of nine selected sites.

\begin{tabular}{|c|c|c|c|c|c|c|c|}
\hline \multirow{2}{*}{ Soil parameters } & \multirow{2}{*}{$N$} & \multirow{2}{*}{ Minimum } & \multirow{2}{*}{ Maximum } & \multirow{2}{*}{ Mean } & \multirow{2}{*}{ Std. Deviation } & \multicolumn{2}{|c|}{ Skewness } \\
\hline & & & & & & Statistic & Std. error \\
\hline $\mathrm{pH}$ & 9 & 4.30 & 7.60 & 7.0444 & 1.03816 & -2.901 & .717 \\
\hline Electrical conductivity $\mathrm{m} \cdot \mathrm{mohs} / \mathrm{cm}$ & 9 & 2.20 & 11.32 & 3.8556 & 2.86815 & 2.733 & .717 \\
\hline Organic matter \%age & 9 & .19 & .76 & .4344 & .21858 & .185 & .717 \\
\hline Available Phosphorous (ppm) & 9 & 3.00 & 11.00 & 6.3333 & 3.08221 & .256 & .717 \\
\hline Available potash (ppm) & 9 & 60.00 & 220.00 & $1.2833 E 2$ & 61.29029 & .228 & .717 \\
\hline Saturation $\%$ age & 9 & 38.00 & 70.00 & 54.8889 & 14.32170 & -.275 & .717 \\
\hline
\end{tabular}

16.0 was applied to ascertain similarity between the sites. Metal concentration in three insect taxa (O. hyla hyla, C. servilia, and D. chrysippus) showed significant differences in accordance with land type at each site. Sites located within industrial area represented higher values of metals in insects than in sites far from them. Heavy metals presented major values in S5 (Small Industrial Area I) with industrial area (Table 6). Lowest value was detected in S6 (Kalra Khasa) located far from industrial area. Cluster analysis was applied to the values of metal concentration for three insect taxa at nine sites. S1 located at the start of Halsi Nala showed different pattern of concentration of metals. CA grouped sampling sites into clusters (called zones in this study) on the basis of similarities within a zone and dissimilarities between different zones. Result of CA helped in interpreting the data and indicating pattern of similar objects. Ward's method was used as a clustering technique to identify the zones in data and square Euclidean distance was used as a distance matrix.

Three zones were identified using CA in each of the insect taxa (Figures 3, 4, and 5). Zone 1 consisted of highly polluted sites namely, 1 and 3 (Start of HalsiNala and Mid of HalsiNala). This zone was restricted to those places that were in close proximity to industrial stagnant waters and seasonal nallahs receiving large volumes of effluents and sewage waste throughout the year. Mid of HalsiNala had stagnant water in which pollutants from urban, industrial waste and agricultural runoff during monsoon are discharged. It is likely that seepage and infiltration of pollutants from nearby running HalsiNala affect the quality and purity of water and soil at this site. Generally level of measured heavy metals was low in this zone in comparison to sites 1, 3, and 9.
3.1. Discussion. Insects are typically the overwhelmingly dominant invertebrate faunal group and extensively used in biomonitoring and bioassessment programs throughout the world. Metals detected in our examined species are as a result of industrial effluents, agricultural runoff, vehicular smoke, domestic and sewage wastes, and use of fertilizers. As these metals are persistent and cannot be degraded by insect metabolism, hence these are accumulated at upper trophic level.

Analytical results obtained during present study are presented for all studied elements, season, insect taxa (species), and sites. As can be expected, insignificant differences were observed in metal concentration for all investigated sampled sites. In grasshoppers as a polyphagous and omnivorous insect, relatively higher contents of heavy metals were found at site "Start of HalsiNala" and "Mid of HalsiNala" that were nearer to the industrial area. As a predator, dragonflies (C. servilia) also had higher contents of heavy metals as it consumes many other insects of that area and thus accumulates high concentration of metals from aquatic environment compared to other two insect groups studied. Butterflies (D. chrysippus) being nectivorous comparatively showed less concentration of heavy metals as compared to other insect taxa studied. These results are in accordance with the observations of Li et al. [15] who point out that some metals contamination like $\mathrm{Cd}$ and $\mathrm{Ni}$ decreases with increased tropic levels.

In the current study all the three insect taxa clearly show site and species dependent metal accumulation patterns for $\mathrm{Cd}, \mathrm{Ni}, \mathrm{Cr}, \mathrm{Zn}$, and $\mathrm{Cu}$. Significantly elevated concentrations were found for $\mathrm{Cd}, \mathrm{Cr}$, and $\mathrm{Cu}$ in "Mid of HalsiNala" > "End of Nala" > "End of Nala" and it thus confirms the expectation that animal body's burden reflects site pollution $(p<0.05)$. 
TABLE 5: Descriptive statistics for soluble salts and other properties in water of nine selected sites.

\begin{tabular}{|c|c|c|c|c|c|c|c|}
\hline \multirow{2}{*}{ Water parameters } & \multirow{2}{*}{$N$} & \multirow{2}{*}{ Minimum } & \multirow{2}{*}{ Maximum } & \multirow{2}{*}{ Mean } & \multirow{2}{*}{ Std. Deviation } & \multicolumn{2}{|c|}{ Skewness } \\
\hline & & & & & & Statistic & Std. error \\
\hline Soluble salts Tss (ppm) & 9 & 505.00 & 1024.00 & $8.6289 E 2$ & 147.47241 & -2.017 & .717 \\
\hline $\mathrm{Ca}^{++} \mathrm{Mg}^{+}$ & 9 & 5.00 & 8.00 & 6.3333 & 1.03078 & .905 & .717 \\
\hline $\mathrm{Na}^{+}$ & 9 & .05 & 4.67 & 2.1967 & 1.25510 & .286 & .717 \\
\hline $\mathrm{HCO}_{3}^{-}$ & 9 & 4.50 & 8.50 & 6.6667 & 1.39194 & -.263 & .717 \\
\hline $\mathrm{Cl}^{-}$ & 9 & .50 & 2.00 & 1.2778 & .61802 & .092 & .717 \\
\hline Sodium absorption ratio (SAR) & 9 & .05 & 2.81 & 1.3800 & .86757 & .206 & .717 \\
\hline
\end{tabular}

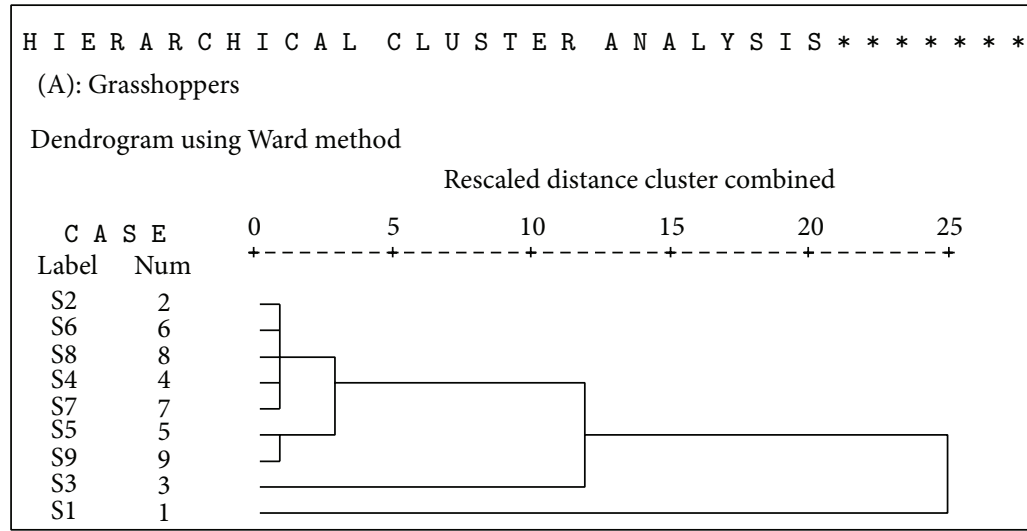

FIGURE 3: Dendrogram of the cluster analysis (using Ward's Method) applied for metal concentration in grasshoppers (O. hyla hyla) at nine sites.

TABLE 6: Test statistics for equal effect of each factor on heavy metal accumulation.

\begin{tabular}{lccc}
\hline Group & Test & Statistics & Significance \\
\hline Season & Mann-Whitney test & 5522.00 & $0.823^{* *}$ \\
\hline \multirow{2}{*}{ Site } & Kruskal-Wallis test & 2.7 & $0.952^{* *}$ \\
& Jonckheere-Terpstra test & 12053.500 & 0.152 \\
\hline \multirow{2}{*}{ Crop } & Mann-Whitney test & 5522 & $0.823^{* *}$ \\
\hline \multirow{2}{*}{ HMG } & Kruskal-Wallis test & 3.225 & $0.521^{* *}$ \\
& Jonckheere-Terpstra test & 10216.500 & $0.868^{* *}$ \\
\hline \multirow{2}{*}{ Metal } & Kruskal-Wallis test & 164.050 & $0.000^{*}$ \\
& Jonckheere-Terpstra test & 4539.00 & $0.000^{*}$ \\
\hline
\end{tabular}

${ }^{*}$ Significant at $5 \%$.

** Significant at $1 \%$.

Less contrasting differences were found for $\mathrm{Ni}$, while $\mathrm{Zn}$ ranges were not significantly different between all sites except at site 3. It might be assumed that in insect metabolism there are physiological mechanisms, which aid in regulations of metal ions concentrations and prevent toxic levels.

For each group of insect species, site and species dependent differences are recorded quite high which can be used as bioindicator of heavy metal stress at particular site and in particular species. Sampling localities found in vicinity of urban areas are suffering with heavy load of metal stress which ultimately results in higher concentrations of $\mathrm{Cd}, \mathrm{Ni}$, $\mathrm{Cr}, \mathrm{Zn}$, and $\mathrm{Cu}$ as compared to less polluted domains side by.
TABLE 7: Variations observed within group in soil parameters.

\begin{tabular}{|c|c|c|c|}
\hline Group 1 & Group 2 & Statistics & Significance \\
\hline \multicolumn{4}{|c|}{ Soil parameters } \\
\hline \multirow{5}{*}{$\mathrm{pH}$} & $\mathrm{EC}$ & 9.0 & $0.004^{*}$ \\
\hline & $\mathrm{OM}$ & 0.00 & $0.000^{*}$ \\
\hline & $\mathrm{AP}$ & 38.0 & 0.863 \\
\hline & $\mathrm{AK}$ & 0.00 & $0.000^{*}$ \\
\hline & S & 0.00 & $0.000^{*}$ \\
\hline \multicolumn{4}{|c|}{ Water parameters } \\
\hline \multirow{5}{*}{ SS (ppm) } & $\mathrm{Ca}^{+}$ & .000 & 0.000 \\
\hline & $\mathrm{Na}^{+}$ & .000 & 0.000 \\
\hline & $\mathrm{HCO}_{3}^{-}$ & .000 & 0.000 \\
\hline & $\mathrm{Cl}^{-}$ & .000 & 0.000 \\
\hline & SAR & .000 & 0.000 \\
\hline
\end{tabular}

${ }^{*}$ Significant at $p<0.05$.

For O. viridulus $59.39 \mathrm{mg} / \mathrm{L}$ of body loads of heavy metals is recorded which enable us to conclude that grasshoppers are good potential metal accumulators.

Taking into account that grasshoppers and butterflies are herbivorous insects and crop type is dependent on soil and water of specific sites, soil and water samples were taken for analysis from same sample sites. An analysis of correlation coefficients (linear, $r^{2}$ ) between metal concentrations and insects, and between soil and water parameters revealed 
TABLE 8: Correlations for each of the insect taxa.

\begin{tabular}{|c|c|c|c|c|c|c|c|c|c|c|c|c|c|c|c|}
\hline \multirow{2}{*}{ Metals } & \multicolumn{5}{|c|}{ Oxya hyla hyla } & \multicolumn{5}{|c|}{ Crocothemis servilia } & \multicolumn{5}{|c|}{ Danaus chrysippus } \\
\hline & $\mathrm{Cu}$ & $\mathrm{Ni}$ & $\mathrm{Zn}$ & $\mathrm{Cr}$ & $\mathrm{Cd}$ & $\mathrm{Cu}$ & $\mathrm{Ni}$ & $\mathrm{Zn}$ & $\mathrm{Cr}$ & $\mathrm{Cd}$ & $\mathrm{Cu}$ & $\mathrm{Ni}$ & $\mathrm{Zn}$ & $\mathrm{Cr}$ & $\mathrm{Cd}$ \\
\hline $\mathrm{Cu}$ & 1 & & & & & 1 & .03 & .53 & .70 & -.06 & 1 & -.42 & .34 & .24 & .02 \\
\hline $\mathrm{Ni}$ & -.17 & 1 & & & & & 1 & -.22 & -.02 & .77 & & 1 & -.28 & .19 & -.05 \\
\hline $\mathrm{Zn}$ & .09 & -.25 & 1 & & & & & 1 & .84 & -.14 & & & 1 & .57 & .06 \\
\hline $\mathrm{Cr}$ & -.36 & -.01 & -.19 & 1 & & & & & 1 & .14 & & & & 1 & -.19 \\
\hline $\mathrm{Cd}$ & -.34 & -.60 & .51 & .45 & 1 & & & & & 1 & & & & & 1 \\
\hline
\end{tabular}

TABLE 9: Correlation of soil parameters.

\begin{tabular}{|c|c|c|c|c|c|c|}
\hline Soil parameters & $\mathrm{pH}$ & $\begin{array}{c}\text { Electrical } \\
\text { conductivity } \\
\mathrm{m} \cdot \mathrm{mohs} / \mathrm{cm}\end{array}$ & $\begin{array}{c}\text { Organic matter } \\
\% \text { age }\end{array}$ & $\begin{array}{c}\text { Available } \\
\text { phosphorous } \\
\text { (ppm) }\end{array}$ & $\begin{array}{l}\text { Available potash } \\
\text { (ppm) }\end{array}$ & Saturation $\%$ age \\
\hline $\mathrm{pH}$ & 1 & & & & & \\
\hline $\begin{array}{l}\text { Electrical } \\
\text { conductivity } \\
\mathrm{m} \cdot \mathrm{mohs} / \mathrm{cm}\end{array}$ & .120 & 1 & & & & \\
\hline $\begin{array}{l}\text { Organic matter \% } \\
\text { age }\end{array}$ & .414 & .568 & 1 & & & \\
\hline $\begin{array}{l}\text { Available } \\
\text { phosphorous } \\
\text { (ppm) }\end{array}$ & .401 & .571 & $.999^{* *}$ & 1 & & \\
\hline $\begin{array}{l}\text { Available potash } \\
\text { (ppm) }\end{array}$ & .413 & .570 & $1.000^{* *}$ & $1.000^{* *}$ & 1 & \\
\hline Saturation \% age & .416 & .414 & $.856^{* *}$ & $.853^{* *}$ & $.853^{* *}$ & 1 \\
\hline
\end{tabular}

${ }^{*}$ Significant at $p<0.05$.

** Significant at $p<0.01$.

TABLE 10: Correlation of water parameters.

\begin{tabular}{|c|c|c|c|c|c|c|}
\hline Water parameters & $\begin{array}{l}\text { Soluble salts Tss } \\
\quad(\mathrm{ppm})\end{array}$ & $\mathrm{Ca}^{++} \mathrm{Mg}^{+}$ & $\mathrm{Na}^{+}$ & $\mathrm{HCO}_{3}^{-}$ & $\mathrm{Cl}^{-}$ & $\begin{array}{c}\text { Sodium } \\
\text { absorption ratio } \\
\text { (SAR) }\end{array}$ \\
\hline Soluble salts Tss (ppm) & 1 & .597 & $.691^{*}$ & $.719^{*}$ & .500 & .578 \\
\hline $\mathrm{Ca}^{++} \mathrm{Mg}^{+}$ & & 1 & -.116 & .392 & .523 & -.254 \\
\hline $\mathrm{Na}^{+}$ & & & 1 & $.684^{*}$ & -.024 & $.850^{* *}$ \\
\hline $\mathrm{HCO}_{3}^{-}$ & & & & 1 & -.170 & .296 \\
\hline $\mathrm{Cl}^{-}$ & & & & & 1 & .291 \\
\hline Sodium absorption ratio (SAR) & & & & & & 1 \\
\hline
\end{tabular}

${ }^{*}$ Significant at $p<0.05$.

** Significant at $p<0.01$.

TABLE 11: Regression analysis for each of the insect taxa.

\begin{tabular}{|c|c|c|c|c|c|c|c|c|c|c|}
\hline \multirow{2}{*}{ HMG group } & \multicolumn{2}{|c|}{ Variables } & \multirow{2}{*}{$\begin{array}{c}\text { Correlation } \\
r \\
\end{array}$} & \multicolumn{5}{|c|}{ Regression coefficients } & \multirow{2}{*}{$\begin{array}{c}R \text { square } \\
R^{2}\end{array}$} & \multirow{2}{*}{$\begin{array}{c}\text { Significance } \\
p\end{array}$} \\
\hline & Dependent & Independent & & $\tilde{\beta}_{0}$ & $\widetilde{\beta}_{1}$ & $\tilde{\beta}_{2}$ & $\tilde{\beta}_{3}$ & $\tilde{\beta}_{4}$ & & \\
\hline \multirow{3}{*}{ O. hyla hyla } & $\mathrm{Cu}$ & $\mathrm{Ni}, \mathrm{Zn}, \mathrm{Cr}$, and $\mathrm{Cd}$ & 0.722 & 128.74 & -6.2 & 1.684 & 3.370 & -258.55 & 0.521 & 0.469 \\
\hline & $\mathrm{Cr}$ & $\mathrm{Ni}, \mathrm{Zn}, \mathrm{Cu}$, and $\mathrm{Cd}$ & 0.79 & 3.92 & 0.026 & 0.501 & -0.08 & 26.25 & 0.63 & 0.30 \\
\hline & $\mathrm{Cd}$ & $\mathrm{Ni}, \mathrm{Zn}, \mathrm{Cr}$, and $\mathrm{Cu}$ & 0.939 & .172 & -0.002 & -0.021 & 0.003 & 0.021 & 0.881 & 0.039 \\
\hline \multirow{3}{*}{ C. servilia } & $\mathrm{Cu}$ & $\mathrm{Ni}, \mathrm{Zn}, \mathrm{Cr}$, and $\mathrm{Cd}$ & 0.722 & 128.74 & -6.214 & 0.684 & 3.370 & -258.55 & 0.521 & 0.469 \\
\hline & $\mathrm{Cr}$ & $\mathrm{Ni}, \mathrm{Zn}, \mathrm{Cu}$, and $\mathrm{Cd}$ & 0.797 & 3.92 & 0.026 & 0.501 & -0.080 & 26.257 & 0.635 & 0.303 \\
\hline & $\mathrm{Cd}$ & $\mathrm{Ni}, \mathrm{Zn}, \mathrm{Cr}$, and $\mathrm{Cu}$ & 0.939 & 0.172 & -0.002 & -0.021 & 0.003 & 0.021 & 0.881 & 0.039 \\
\hline \multirow{3}{*}{ D. chrysippus } & $\mathrm{Cu}$ & $\mathrm{Ni}, \mathrm{Zn}, \mathrm{Cr}$, and $\mathrm{Cd}$ & 0.547 & 75.446 & -15.492 & -0.17 & 10.88 & 52.27 & 0.299 & 0.785 \\
\hline & $\mathrm{Cr}$ & $\mathrm{Ni}, \mathrm{Zn}, \mathrm{Cu}$, and $\mathrm{Cd}$ & 0.751 & 4.27 & 0.008 & 0.482 & 0.024 & -5.365 & 0.564 & 0.404 \\
\hline & $\mathrm{Cd}$ & $\mathrm{Ni}, \mathrm{Zn}, \mathrm{Cr}$, and $\mathrm{Cu}$ & 0.328 & 0.108 & 0.398 & 0.000 & 0.007 & 0.001 & -0.019 & 0.968 \\
\hline
\end{tabular}




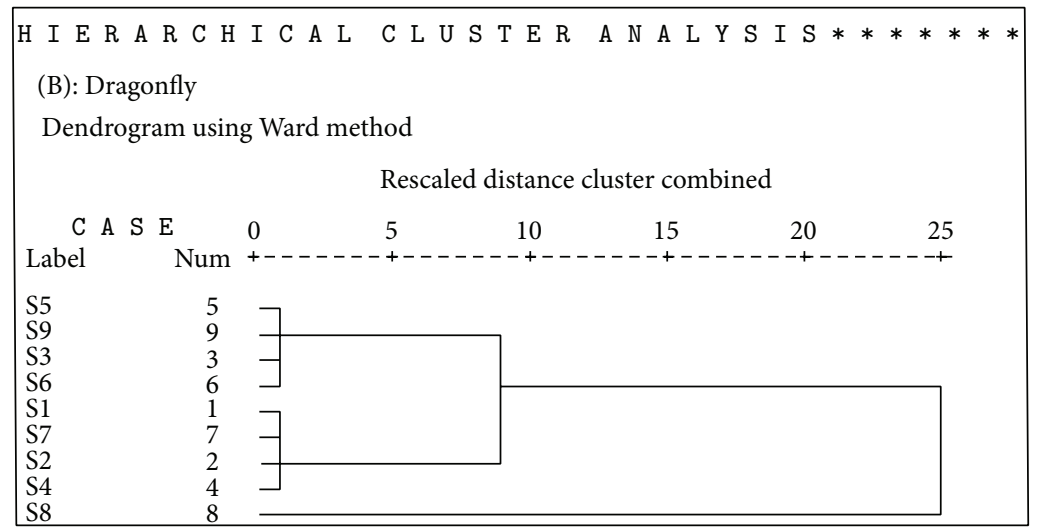

FIgURE 4: Dendrogram of the cluster analysis (using Ward's Method) applied for metal concentration in dragonfly (C. servilia) at nine sites.

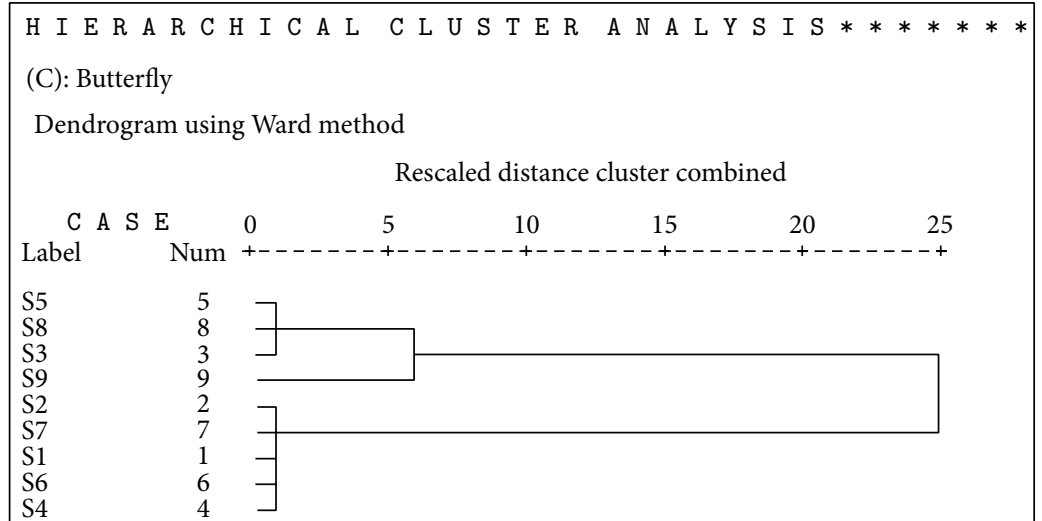

FiguRE 5: Dendrogram of the cluster analysis (using Ward's Method) applied for metal concentration in butterfly (D. chrysippus) at nine sites.

significant $(p<0.05)$ relationship (Table 10). Our study found positive correlation between $\mathrm{Cd}, \mathrm{Cu}$, and $\mathrm{Cr}$ for each of the examined species, but not between $\mathrm{Zn}$ and $\mathrm{Ni}$ although $\mathrm{Zn}$ can be replaced by $\mathrm{Cd}$.

Urban expansion and further development of industries, tanneries in the city would most likely enhance pollution. One of the major concerns is untreated industrial and municipal sewage pollution which poses major threat to the River Chenab, which is regarded as a pristine aquatic resource of Punjab province. Similarly lives of flora, fauna, and above all humans are at risk due to these untreated and regularly increasing industrial and urban wastes.

\section{Conclusions}

The present study highlights the extent of threat to insect and human lives in industrial area of Gujrat as a result of increasing metal concentration of $\mathrm{Cu}, \mathrm{Cr}, \mathrm{Cd}, \mathrm{Zn}$, and $\mathrm{Ni}$. It also brings forward scope of different insects to be used as tool to study environment quality and conditions. The study thus advocates a need for proper measures to be taken to lessen increasing environmental pollution (soil, air, and water) by strictly implementing pollution control laws and enforcing proper disposal of industrial effluents in industrial zones.

\section{Conflict of Interests}

The authors declare that there is no conflict of interests regarding the publication of this paper.

\section{References}

[1] A. Qadir and R. N. Malik, "Assessment of an index of biological integrity (IBI) to quantify the quality of two tributaries of river Chenab, Sialkot, Pakistan," Hydrobiologia, vol. 621, no. 1, pp. 127-153, 2009.

[2] Z. Atafar, A. Mesdaghinia, J. Nouri et al., "Effect of fertilizer application on soil heavy metal concentration," Environmental Monitoring and Assessment, vol. 160, no. 1-4, pp. 83-89, 2010.

[3] C. S.-L. Lee, X. Li, W. Shi, S. C.-N. Cheung, and I. Thornton, "Metal contamination in urban, suburban, and country park soils of Hong Kong: a study based on GIS and multivariate statistics," Science of the Total Environment, vol. 356, no. 1-3, pp. 45-61, 2006.

[4] A. J. Davis, J. D. Hollowary, H. Huijbregts, J. Krikken, A. H. Kirk-Spriggs, and S. L. Sutton, "Dung beetles as indicators of change in the forests of northern Borneo," Journal of Applied Ecology, vol. 38, no. 3, pp. 593-616, 2001.

[5] W. Sildanchandra and M. Crane, "Influence of sexual dimorphism in Chironomus riparius Meigen on toxic effects of 
cadmium," Environmental Toxicology and Chemistry, vol. 19, no. 9, pp. 2309-2313, 2000.

[6] A. Zia, M. A. Rafi, Z. Hussain, and M. Naeem, "Occurrence of Odonata in northern area of Pakistan with seven new records," Halteres, vol. 1, no. 1, pp. 48-56, 2009.

[7] A. Zia, Biosystematics of damselflies (Zygoptera: Odonata) of Pakistan [Ph.D. thesis], PMAS-Arid Agriculture University, Rawalpindi, Pakistan, 2010.

[8] M. A. Rafi, M. R. Khan, A. Zia, and A. Shehzad, "Diversity of Odonata in district Poonch and Sudhnoti of Kashmir ValleyPakistan, with a new record for the country," Halteres, vol. 1, no. 1, pp. 28-35, 2009.

[9] A. Zia, M. Naeem, and S. A. Hassan, "A list of damselflies (Zygoptera: Odonata) recorded from Azad Jammu and Kashmir (AJ\&K)," Pakistan Journal of Science and Industrial Research, vol. 51, no. 1, pp. 329-332, 2008.

[10] T.-B. Chen, Y.-M. Zheng, M. Lei et al., "Assessment of heavy metal pollution in surface soils of urban parks in Beijing, China," Chemosphere, vol. 60, no. 4, pp. 542-551, 2005.

[11] C. Y. Niu, Y. Jiang, C. L. Lei, and C. Hu, "Effects of cadmium on housefly: influence on growth and development and metabolism during metamorphosis of housefly," Entomologia Sinica, vol. 9, no. 1, pp. 27-33, 2002.

[12] A. Cervera, A. C. Maymó, M. Sendra, R. Martínez-Pardo, and M. D. Garcerá, "Cadmium effects on development and reproduction of Oncopeltus fasciatus (Heteroptera: Lygaeidae)," Journal of Insect Physiology, vol. 50, no. 8, pp. 737-749, 2004.

[13] A. Qadir, R. N. Malik, and S. Z. Husain, "Spatio-temporal variations in water quality of Nullah Aik-tributary of the river Chenab, Pakistan," Environmental Monitoring and Assessment, vol. 140, no. 1-3, pp. 43-59, 2008.

[14] R. N. Malik and S. Z. Husain, "Classification and ordination of vegetation communities of the lohibehr reserve forest and its surrounding areas, Rawalpindi, Pakistan," Pakistan Journal of Botany, vol. 38, no. 3, pp. 543-558, 2006.

[15] X. Li, S.-I. Lee, S.-C. Wong, W. Shi, and I. Thornton, “The study of metal contamination in urban soils of Hong Kong using a GIS-based approach," Environmental Pollution, vol. 129, no. 1, pp. 113-124, 2004. 

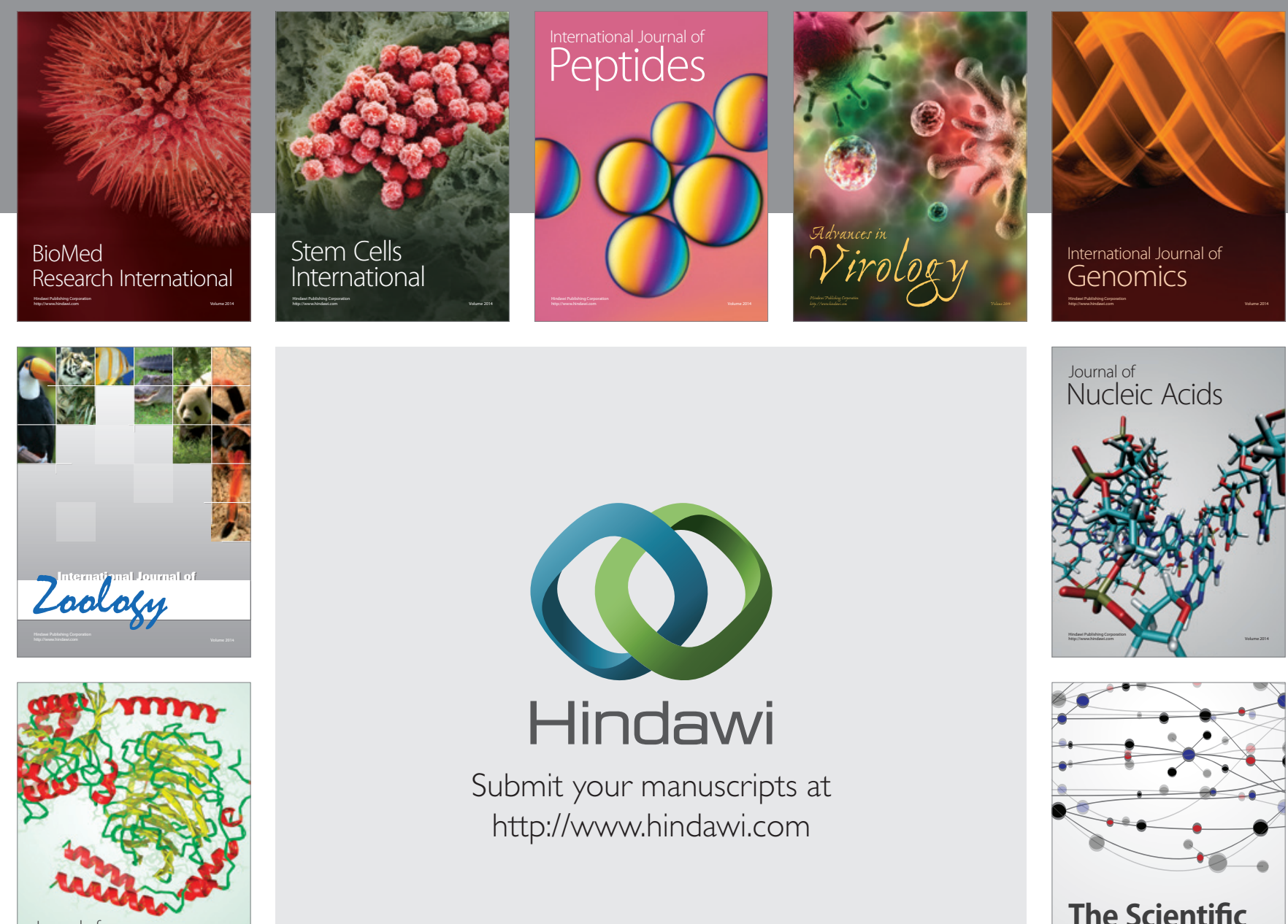

Submit your manuscripts at

http://www.hindawi.com

Journal of
Signal Transduction
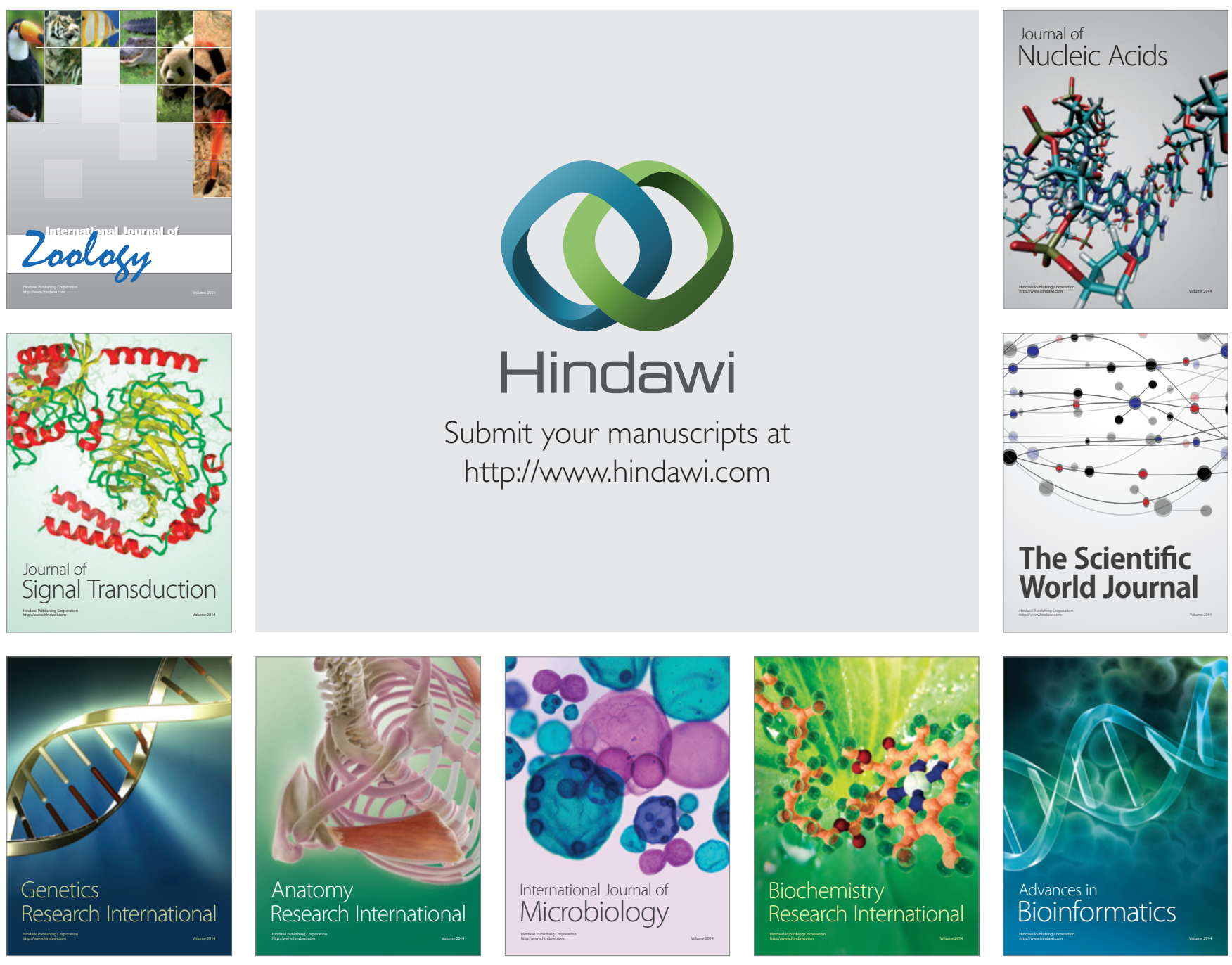

The Scientific World Journal
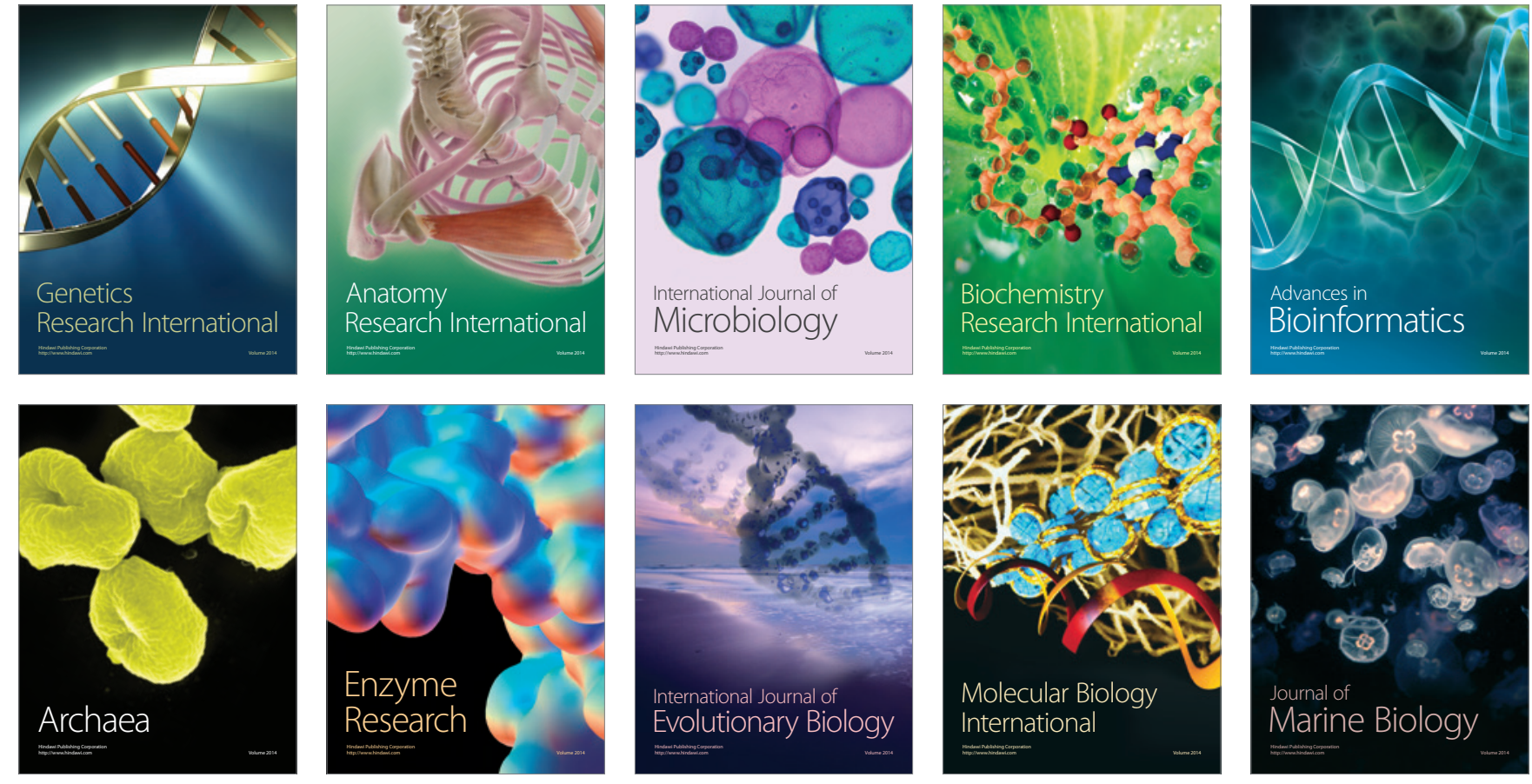